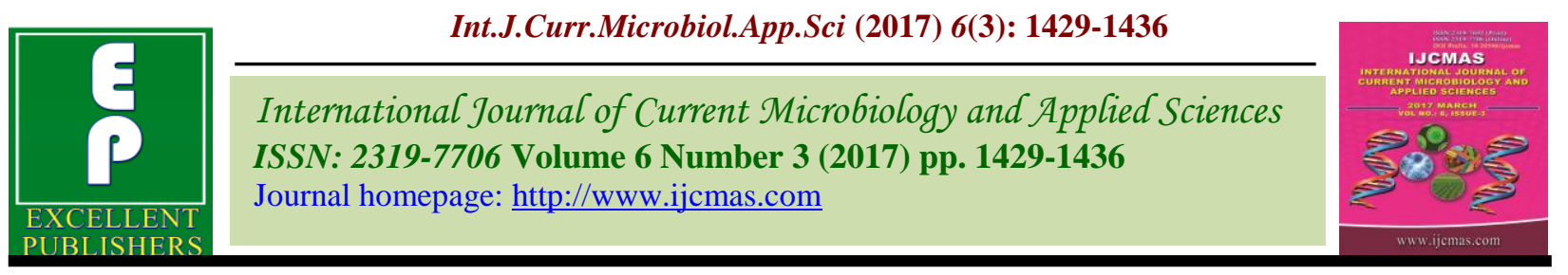

Original Research Article

https://doi.org/10.20546/ijcmas.2017.603.162

\title{
Effect of Integrated Nutrient Management on Productivity and Nutrients Availability of Potato
}

\author{
Pradip Kumar $^{1}$, Alok Kumar ${ }^{1}$, Neeraj Kumar ${ }^{1}$, Atik Ahamad ${ }^{1}$ and M.K. Verma ${ }^{2}$ \\ ${ }^{1}$ Department of Soil Science and Agricultural Chemistry NDUAT Kumarganj, Faizabad, \\ Uttar Pradesh- 224229, India \\ ${ }^{2}$ Department of Soil Science and Agricultural Chemistry, IAS, BHU, Varanasi, Uttar Pradesh- \\ 221005, India \\ *Corresponding author
}

\begin{tabular}{|c|c|}
\hline & A B S T R A C T \\
\hline & \multirow{7}{*}{$\begin{array}{l}\text { A field experiment was conducted at Agronomy Research Farm of N.D.U.A.\&T. } \\
\text { Kumarganj, Faizabad, during the Rabi season of } 2012-13 \text { to assess the growth, yield and } \\
\text { nutrient availability as affected by integrated nutrient management of potato crop. The } \\
\text { twelve treatments comprised with various levels of Tata Geo Green (as well matured } \\
\text { compost prepared from byproducts of sugarcane industry) and Farm Yard Manure with } \\
75 \% \text { and } 100 \% \text { NPK fertilizers were tested against } 100 \% \text { fertilizers alone. Application of } \\
\text { integrated use of Tata Geo Green @ } 3.75 \text { t/ha along with } 75 \% \text { recommended dose of NPK } \\
\text { fertilizer (150:60:100) in potato was found superior for higher plant growth. The } \\
\text { availability of N, P, K nutrients and organic carbon in soil increased at higher rate by } \\
\text { applying TGG and FYM along with fertilizers as compared to chemical fertilizers alone. } \\
\text { The application of Tata Geo Green @ } 3.75 \text { t/ha along with } 75 \% \text { recommended dose of } \\
\text { chemical fertilizers provided highest net returns (Rs.133205) and Rs. /Re invested (1.34). } \\
\text { It was concluded that application of TGG @ } 3.75 \text { with } 75 \% \text { RDF may be recommended } \\
\text { for higher productivity and returns. }\end{array}$} \\
\hline Keywords & \\
\hline $\begin{array}{l}\text { Growth, Available } \\
\text { nutrient, }\end{array}$ & \\
\hline Economics, Potato. & \\
\hline Article Info & \\
\hline $\begin{array}{l}\text { Accepted: } \\
\text { 22 February } 2017 \\
\text { Available Online: } \\
10 \text { March } 2017\end{array}$ & \\
\hline & \\
\hline
\end{tabular}

\section{Introduction}

Potato is the fourth most important food crop after rice, wheat and maize in the North-East plains of India. India is the second largest potato producing country in the world after China, with annual production of 42.48 million tonnes from area of 1.93 million hectare, while in Uttar Pradesh area, production and productivity of potato is 0.55 $\mathrm{m}$ ha, $13.57 \mathrm{~m}$ tonnes and 24.67 tonnes ha ${ }^{-1}$, respectively (Anonymous, 2013). Being a heavy feeder of nutrients, potato required high amount of nitrogen, phosphorus and potassium.
Chemical fertilizer is the main source of nutrients use for potato cropping. However, continuous dependence of chemical fertilizer causes nutritional balance and adverse effects on physic-chemicals and biological properties of soil. Integrated nutrient management is a bitter approach for supplying nutrient or food to the crop by including organic and inorganic source of nutrient (Arora, 2008). Further imbalance and indiscriminate use of chemical fertilizers and pesticides resulted several harmful effects on soil, water and air causing 
their pollution. This has reduced the productivity of the soil by deteriorating soil health in terms of soil fertility and biological activity. Excessive use of agrochemicals under intensive cultivation has disturbed the harmony which existed among soil, plant, biolife, animals and human beings. Thus, integrated approach of nutrient supply by chemical fertilizers along with organic manures is giving an importance especially in heavy feeder crops. Further, considerable improvement in quantity and quality of exhaustive and responsive crop like potato has been observed under integrated use of organic and inorganic fertilizers as compared to recommended dose of nutrients applied with inorganic fertilizers alone (Raghav et al., 2009 and Bhaishya et al., 2012).

\section{Materials and Methods}

The field experiment was conducted during Rabi season in 2012-13 at Agronomy Research Farm of NDUA\&T Kumarganj, Faizabad (U.P.). It lies at $26^{\circ} 47^{\prime} \mathrm{N}$ latitude, $82^{0} 12^{\prime} \mathrm{E}$ longitude and an altitude $113 \mathrm{~m}$ above the mean sea level. The available N, P and $\mathrm{K}$ content of the soil were 114.0, 13.5 and $246.0 \mathrm{~kg} \mathrm{ha}^{-1}$, respectively with bulk density $1.38\left(\mathrm{Mg} \mathrm{m}^{-3}\right), \mathrm{pH} 8.30$, EC $0.33\left(\mathrm{dSm}^{-1}\right)$ and OC- $0.40 \%$. Tata geo green free from weed seeds and disease causing microbes, having 2 to $2.5 \%$ nitrogen, $4 \%$ phosphorus, $3 \%$ calcium, $1 \%$ magnesium $1.25 \%$ sulphur, 100 ppm zinc and $300 \mathrm{ppm}$ manganese and other micronutrients e.g. $\mathrm{Cu}, \mathrm{Bo}, \mathrm{Fe}$. It also contains organic matter $30 \%$ of biomass, $\mathrm{pH}$ 6.5 to 7.5 and organic carbon $18-21 \%$.

There were twelve treatment combinations viz. $\mathrm{T}_{1}-\mathrm{TGG} 2.5 \mathrm{t} \mathrm{ha}^{-1}+100 \% \mathrm{RDF}, \mathrm{T}_{2}-$ TGG $3.75 \mathrm{t} \mathrm{ha}^{-1}+100 \%$ RDF, $\mathrm{T}_{3}$ - TGG $5 \mathrm{t}$ ha ${ }^{1}+100 \%$ RDF, T $4^{-}$TGG $2.5 \mathrm{t} \mathrm{ha}^{-1}+75 \%$ RDF, T $5^{-}$TGG $3.75 \mathrm{t} \mathrm{ha}^{-1}+75 \% \mathrm{RDF}^{-} \mathrm{T}_{6^{-}}$ TGG $5 \mathrm{t} \mathrm{ha}^{-1}+75 \%$ RDF, T 7 - FYM $12.5 \mathrm{t} \mathrm{ha}^{-1}$ $+100 \%$ RDF, T 8 - FYM $25 \mathrm{t} \mathrm{ha}^{-1}+100 \%$
RDF , T $^{-}$FYM $12.5 \mathrm{t} \mathrm{ha}^{-1}+75 \%$ RDF, $\mathrm{T}_{10}-$ FYM $25 \mathrm{t} \mathrm{ha}^{-1} 75 \%$ RDF, $\mathrm{T}_{11^{-}} 100 \% \mathrm{RDF}$ and $\mathrm{T}_{12^{-}}$Control were replicated thrice in a Randomized Block Design. Potato variety Kufri Lalima was used in this study. In addition to this, half quantity of nitrogen and full quantity of phosphorus and potassium were also applied as per treatment through urea, diammonium phosphate and muriate of potash, respectively. The remaining half quantity of nitrogen was top dressed in furrows at the time of earthing up. Potato tubers were planted in the ridge $45 \mathrm{~cm}$ apart with plant to plant distance of $10 \mathrm{~cm}$ in the November, 2012.

All the growth parameters were studied, plant height was measured from the base of the plants to the apex at 45 and 60 DAP, number of haulms per hill was counted at 60 days after planting. The yield parameters were collected at harvest i.e. 120 days after Planting. For determining specific gravity, the tubers of each grade were taken randomly from each plot. Tubers were weighed separately and then they were placed into measuring cylinder containing water. Thus, water which was replaced by the tubers was measured and specific gravity was calculated adopting the following formula:

Specific gravity $=$

$$
\text { Weight of tubers (g) }
$$

Volume of water replaced by the tubers $(\mathrm{ml})$

\section{Chemicals analysis}

Chemical properties of organic carbon was determined by Walkey and Black (1934), available $\mathrm{N}$ by alkaline Potassium Permanganate method (Subbiah and Asajia, 1956), available P by Olsen's method (Olsen et al., 1954) and available $\mathrm{K}$ by Ammonium Acetate Extraction method (Jackson, 1973). 


\section{Statistical analysis}

The analysis of variance methods (Snedecor and Cochran, 1967) was followed to statistically analyze the various data. The significance of different sources of variations was tested by Error mean square of Fisher Snedecor's ' $F$ ' test at probability level $(P=$ $0.05)$. In the summery tables of the results, the standard error of mean (Sem \pm ), the value of critical difference (CD) and coefficient of variation $(\mathrm{CV})$ to compare the difference between the means have been provided.

\section{Results and Discussion}

\section{Plant height (cm)}

Highest plant height was recorded at 45 days after planting with TGG $5 \mathrm{t} \mathrm{ha}^{-1}+100 \%$ RDF, which was significant higher than other treatments combination. The data showed that 60 DAP about $10-14 \mathrm{~cm}$ increase in plant height during 15 days (45 to $60 \mathrm{DAP}$ ) (Table 1). The maximum plant height $(49.2 \mathrm{~cm})$ was recorded with treatments $\mathrm{T}_{6}$ receiving TGG @ $5 \mathrm{t} \mathrm{ha}^{-1}$ along with $75 \%$ RDF, which was remained at par to all the integrated nutrient management treatments receiving various levels of TGG $\left(2.5,3.75\right.$ and $\left.5 \mathrm{t} \mathrm{ha}^{-1}\right)$ and FYM (12.5 and $25 \mathrm{t} \mathrm{ha}^{-1}$ ) along with $75 \%$ and $100 \%$ RDF or $100 \%$ RDF alone. Plant height recorded at 45 days after planting (DAP) revealed that there was no significant difference among the treatments receiving various levels of Tata geo green $(2.5,3.75$ and $5 \mathrm{t} / \mathrm{ha})$ and farm yard manure (12.5 and 25 t/ha) along with $75 \%$ and $100 \%$ recommended doses of NPK fertilizers (RDF) or $100 \%$ RDF alone. Pandey et al., (2008) studied the various options of nutrient management in potato and reported that plant growth parameters (plant height) remains unaffected up to $50 \%$ replacement of inorganic by organics sources but yield decreased significantly.

\section{Number of haulms hill ${ }^{-1}$}

The number of haulms/ hill at 60 days after planting (DAP) has been given in (Table 1) number of haulms hill ${ }^{-1}$ were not influenced significantly due to application of various doses of Tata geo green $\left(2.5,3.75\right.$ and $5 \mathrm{tha}^{-}$ ${ }^{1}$ ) and farm yard manure (12.5 and $\left.25 \mathrm{t} \mathrm{ha}^{-1}\right)$ along with 75 and $100 \%$ chemical fertilizers alone as compared to $100 \%$ recommended chemical fertilizers alone. The maximum number of haulms hill-1 (5.26) was recorded in the treatment receiving farm yard manure $25 \mathrm{t}+75 \% \operatorname{RDF}\left(\mathrm{T}_{10}\right)$, which remained at par to all the manure treatments $\left(\mathrm{T}_{1}\right.$ to $\mathrm{T}_{9}$ and $\left.\mathrm{T}_{11}\right)$ in which the number of haulms hill ${ }^{-1}$ varied from 4.90-5.26.

\section{Haulms (q ha $\left.{ }^{-1}\right)$}

The results showed (Table 1) significant variation in haulms production due to the different nutrient management practices. The highest haulms production was obtained with the application of FYM $25 \mathrm{tha}^{-1}+100 \%$ RDF, but it was statistically at par with treatment $T_{3}, T_{6}$ and $T_{2}$. The application of organic manures viz., TGG and FYM along with chemical fertilizers increased haulm (plant biomass) production significantly compared to chemical fertilizers alone. The increase in dose of FYM (12.5 to $\left.25 \mathrm{t} \mathrm{ha}^{-1}\right)$ and Tata geo green (2.5 to $5.0 \mathrm{t} / \mathrm{ha})$ also increased haulm production significantly similarly reported by Krishnamurthy et al., (2002).

\section{Specific gravity $\left(\mathrm{g} \mathrm{cm}^{-3}\right)$}

Specific gravity of tubers increased significantly by applying organic manures viz., Tata geo green and farm yard manure along with $75 \%$ and $100 \%$ recommended dose of NPK fertilizers as compared to $100 \%$ RDF alone. However, no significant variations were observed among the various 
levels of organic manures (FYM and TGG). Similar results have been reported by Mandal et al., (2005); Gauhar and Raghav (2008) and Bhaishya et al., (2012).

\section{Total Tuber Yield $\left(\mathbf{q} \mathbf{h a}^{-1}\right)$}

The pooled yield data showed that application of Tata geo green and farm yard manure along with chemical fertilizers increased the total tuber yield significantly as compared to 100\% chemical fertilizers alone (Table 1). Presence of plant growth influencing substances such as plant growth hormones and humic acid and organic manures might be a possible factor contributing to increase yield
(Das et al., 2002). The increasing level of TGG from $2.5 \mathrm{t} / \mathrm{ha}$ to $3.75 \mathrm{t} / \mathrm{ha}$ increased the tuber yield significantly, but further increase in the dose of TGG (3.75 to $5 \mathrm{t} / \mathrm{ha})$ was not resulted a significant increase in tuber yield at both the levels of chemical fertilizers $(75 \%$ and $100 \%)$. Similarly, the increase in the dose of FYM from 12.5 to $25 \mathrm{t} \mathrm{ha}^{-1}$ increased total tuber yield significantly at both the levels of recommended doses $(75 \%$ and $100 \%)$ of fertilizers. Among the organic sources, Tata geo green was found more responsive than farm yard manure in terms of productivity of tubers.

Table.1 Effect of integrated nutrient management on plant height at 45 and 60 days after planting

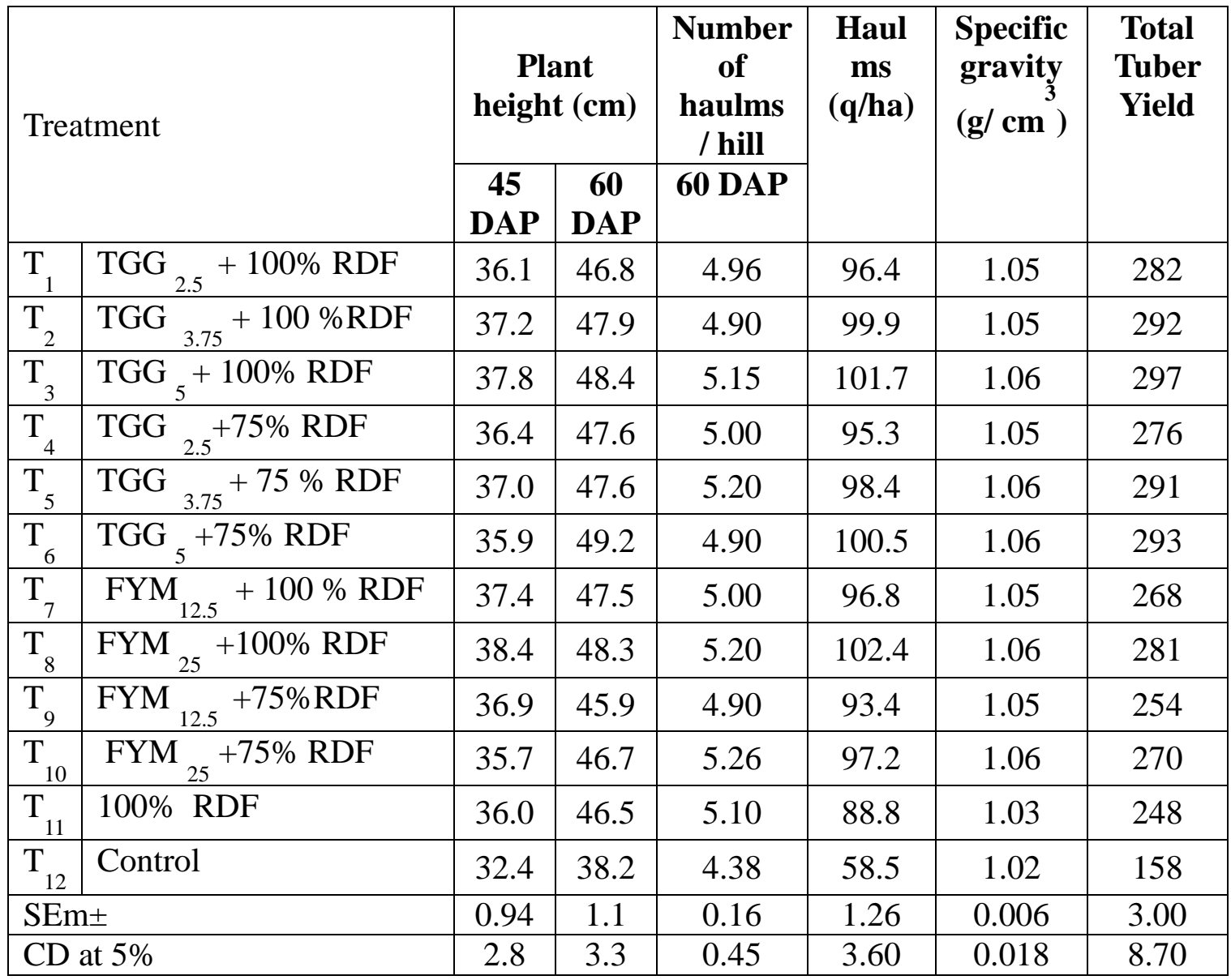


Table.2 Effect of integrated nutrient management on nutrients availability after harvest of potato

\begin{tabular}{|c|c|c|c|c|c|}
\hline \multicolumn{2}{|r|}{ Treatment } & $\begin{array}{l}\text { O.C. } \\
(\%)\end{array}$ & $\begin{array}{c}\text { Available } \mathbf{N} \\
\text { (kg/ha) }\end{array}$ & $\begin{array}{c}\text { Available P } \\
\text { (kg/ha) }\end{array}$ & $\begin{array}{c}\text { Available K } \\
\text { (kg/ha) }\end{array}$ \\
\hline $\mathrm{T}_{1}$ & $\mathrm{TGG}_{2.5}+100 \% \mathrm{RDF}$ & 0.56 & 148 & 18.5 & 148 \\
\hline $\mathrm{T}_{2}$ & $\mathrm{TGG}_{3.75}+100 \% \mathrm{RDF}$ & 0.59 & 153 & 19.8 & 153 \\
\hline $\mathrm{T}_{3}$ & $\mathrm{TGG}_{5}+100 \% \mathrm{RDF}$ & 0.60 & 160 & 22.0 & 160 \\
\hline $\mathrm{T}_{4}$ & TGG $_{2.5}+75 \%$ RDF & 0.55 & 143 & 16.8 & 143 \\
\hline $\mathrm{T}_{5}$ & TGG $_{3.75}+75 \%$ RDF & 0.58 & 148 & 18.5 & 148 \\
\hline $\mathrm{T}_{6}$ & $\mathrm{TGG}_{5}+75 \% \mathrm{RDF}$ & 0.60 & 155 & 19.4 & 155 \\
\hline $\mathrm{T}_{7}$ & $\mathrm{FYM}_{12.5}+100 \% \mathrm{RDF}$ & 0.54 & 148 & 18.9 & 148 \\
\hline $\mathrm{T}_{8}$ & $\mathrm{FYM}_{25}+100 \% \mathrm{RDF}$ & 0.58 & 156 & 21.2 & 156 \\
\hline $\mathrm{T}_{9}$ & $\mathrm{FYM}_{12.5}+75 \% \mathrm{RDF}$ & 0.53 & 144 & 17.8 & 144 \\
\hline $\mathrm{T}_{10}$ & $\mathrm{FYM}_{25}+75 \% \mathrm{RDF}$ & 0.57 & 152 & 20.1 & 152 \\
\hline $\mathrm{T}_{11}$ & $100 \% \mathrm{RDF}$ & 0.49 & 134 & 17.2 & 134 \\
\hline $\mathrm{T}_{12}$ & Control & 0.42 & 118 & 13.0 & 118 \\
\hline \multicolumn{2}{|c|}{ SEm \pm} & 0.01 & 3.17 & 0.62 & 3.17 \\
\hline \multicolumn{2}{|c|}{$\mathrm{CD}$ at $0.05 \%$} & 0.03 & 9.2 & 1.8 & 9.2 \\
\hline
\end{tabular}

Table.3 Economics of potato cultivation influenced by various nutrient combinations

\begin{tabular}{|c|c|c|c|c|}
\hline Treatment & $\begin{array}{c}\text { Gross income (Rs/ } \\
\text { ha) }\end{array}$ & $\begin{array}{c}\text { Total cost of } \\
\text { cultivation } \\
\text { (Rs/ ha) }\end{array}$ & $\begin{array}{c}\text { Net income (Rs } \\
\text { /ha) }\end{array}$ & $\begin{array}{c}\text { BCR (Rs/ } \\
\text { Re } \\
\text { invested) }\end{array}$ \\
\hline $\mathbf{T}_{\mathbf{1}}$ & 226400 & 96260 & 129340 & 1.34 \\
\hline $\mathbf{T}_{\mathbf{2}}$ & 233600 & 101260 & 132340 & 1.31 \\
\hline $\mathbf{T}_{\mathbf{3}}$ & 237600 & 106260 & 131340 & 1.24 \\
\hline $\mathbf{T}_{\mathbf{4}}$ & 220800 & 94595 & 126205 & 1.33 \\
\hline $\mathbf{T}_{\mathbf{5}}$ & 232800 & 99595 & 133205 & 1.34 \\
\hline $\mathbf{T}_{\mathbf{6}}$ & 234400 & 104595 & 129805 & 1.24 \\
\hline $\mathbf{T}_{\mathbf{7}}$ & 214400 & 94385 & 120015 & 1.27 \\
\hline $\mathbf{T}_{\mathbf{8}}$ & 224800 & 102510 & 122290 & 1.19 \\
\hline $\mathbf{T}_{\mathbf{9}}$ & 203200 & 92720 & 110480 & 1.19 \\
\hline $\mathbf{T}_{\mathbf{1 0}}$ & 216000 & 100845 & 115155 & 1.14 \\
\hline $\mathbf{T}_{\mathbf{1 1}}$ & 198400 & 86260 & 112140 & 1.30 \\
\hline $\mathbf{T}_{\mathbf{1 2}}$ & 126400 & 79600 & 46800 & 0.59 \\
\hline
\end{tabular}


Raghav et al., (2009) reported maximum tuber yield of potato $\left(270 \mathrm{q} \mathrm{ha}^{-1}\right)$ under the treatment receiving combinations of organic manures (FYM, poultry manure, vermicompost) which was $7.0 \%$ higher than $100 \%$ recommended doses of chemical fertilizers. Similar observations have also been noted by Singh et al., (2008) and Islam et al., (2013).

\section{Effect on soil nutrient status after harvest}

The data recorded on soil properties as influenced by various treatments have been given in table 2. Significantly higher values of organic carbon percentage, available $\mathrm{N}, \mathrm{P}_{2} \mathrm{O}_{5}$ and $\mathrm{K}_{2} \mathrm{O}$ content in soil were recorded in application of $\mathrm{T}_{3}$ - TGG $5 \mathrm{t} \mathrm{ha}^{-1}+100 \% \mathrm{RDF}$. The organic carbon also increased significantly with increasing doses of TGG from 2.5 to 5 t/ha and FYM from 12.5 to 25 t/ha at both the levels (75\% and $100 \%)$ of chemical fertilizers. This could be attributed to direct addition of organic substances in soil and due to better root growth, more plant residues after crop harvest and their indirect influence on physico-chemical characteristics of the soil (Kaushik et al., 1984 and Ojha et al., 2009).

It was also observed that available nitrogen increased significantly with increasing levels of TGG from 2.5 to $5 \mathrm{t} / \mathrm{ha}$. The increase in available nitrogen with increasing doses of FYM from 12.5 to $25 \mathrm{tha}^{-1}$ was also noticed but not to the extent of significance. The increase in soil nitrogen might be due to direct addition of $\mathrm{N}$ through fertilizer and organic materials and greater multiplication of soil microbes, which converts organically bound nitrogen to inorganic form (Bellakki and Badanur, 1997). Manjappa (1999) also founded that inclusion of organic manures such as FYM, vermicompost, cotton and safflower stalk enhanced the soil available nitrogen more as compared to recommended dose of fertilizers alone.
The application of higher quantity of Tata geo green $\left(5 \mathrm{t} \mathrm{ha}^{-1}\right)$ and farm yard manure $\left(25 \mathrm{tha}^{-1}\right)$ along with chemical fertilizers increased available phosphorus significantly as compared to $100 \%$ chemical fertilizers alone. Selvamani et al., (2011) reported that phosphorus content in soil increased the significantly by application of organics and bio-inoculants in rice. Organic acids released during decomposition of organic manures increased availability of phosphorus. The organic materials form a protective cover on sesquoxide and thus also reduce the phosphate fixing capacity of soil and hence, increase available $\mathrm{P}$ status of soil (Singh et al., 2006). The significant build up in available potassium was recorded with increasing levels of TGG from 2.5 to $5.0 \mathrm{t} / \mathrm{ha}$. The application of Tata geo green increased more potassium than farm yard manure.

The application of organic manures (Tata geo green and farm yard manure) along with the chemical fertilizers increased available potassium significantly as compared to $100 \%$ chemical fertilizers alone. The significant build up in available potassium was recorded with increasing levels of TGG from 2.5 to 5.0 $\mathrm{t} / \mathrm{ha}$. The application of Tata geo green increased more potassium than farm yard manure. The organic manures have greater capacity to hold $\mathrm{K}$ in available form and reduced K-fixation due to interaction of organic matter with clay besides direct addition of potassium to the available pool of soil (Mathur, 1997). Selvamani et al., (2011) reported maximum potassium content in soil with application of 50\% RDF through inorganic fertilizers with FYM, vermicompost, neem cake and biofertilizers.

\section{Economics}

The data (Table 3) revealed that maximum net return (Rs. 133205 /ha) and benefit-cost ratio (1.34 Rs per Re invested) were obtained by applying Tata geo green @ $3.75 \mathrm{t} \mathrm{ha}^{-1}$ along 
with $75 \%$ recommended dose of chemical fertilizers. The application of TGG with fertilizers provided higher net returns as compared to FYM with fertilizers. The chemical fertilizers alone also provided higher benefit-cost ratio (Rs. 1.30 Rs per Re invested) as compared to $5 \mathrm{t} \mathrm{TGG} \mathrm{ha}{ }^{-1}, 12.5 \mathrm{t}$ FYM ha ${ }^{-1}$ and $25 \mathrm{t} \mathrm{FYM} \mathrm{ha}^{-1}$ along with fertilizers, similarly reported by (Chettri and Thapa, 2004).

In conclusion, the integrated use of Tata geo green @ 3.75 t/ha along with 75\% recommended dose of NPK fertilizer (150:60:100) in potato was found superior and recommended for higher productivity and better marketable quality of tubers. The integrated application of Tata geo green @3.75 t/ha along with $75 \%$ recommended dose of chemical fertilizers provided maximum net returns and Rs per Re invested (benefit-cost ratio).

\section{References}

Annonymous. 2013. Estimates of potato production, Directorate of Economics. Ministry of Agriculture, New Delhi.

Arora. 2008. Balance nutitional for sustainable crop production. Krishi world, 1-5.

Baishya, M.K., Ghosh, L.K., Gupta, D.C., Dubey, V.K., Anup, S.K. and Patel, D.P. 2012. Productivity and soil health of potato (Solanum tuberosum L.) field as influenced by organic manures, inorganic fertilizers and biofertilizers under high altitudes of Eastern Himalayas. J. Agril. Sci., (Toronto); 4(5): 223-234.

Bellakki, M.A., and Badanur, V.P. 1997. Long-term effect of integrated nutrient management on properties of Vertisol under dryland agriculture. J. Indian Soc. Soil Sci., 45: 438-442.

Chettri, M., and Thapa, U. 2004. Integrated nutrient management with farm yard manure on potato (Solanum tuberosum) under gangetic plains of West Bengal. Environ. Ecol., 22(4): 766-769.

Gauhar, S., and Raghav, M. 2008. Effect of integrated nutrient management on yield and quality of potato (Solanum tuberosum L.). Pantnagar J. Res., 6(1): 122-124.

Islam, M.M., Majid, S.A., Jannatul, N.M., and Ferdous Alam, M.S. 2013. Integrated nutrient management for potato (Solanum tuberosum) in grey terrace soil (Aric Albaquipt). Australian J. Crop Sci., 7(9): 1235-1241.

Jackson, M.L. 1973. Soil chemical analysis. Prentice Hall of India. Pvt. Ltd. New Delhi. 186-192,

Kaushik, R.D., Verma, K.S., Dang, Y.P., Sharma, A.P., Verma, S.I. and Pannu, B.S. 1984. Effect of nitrogen and farm yard manure on yield of crops, nutrients uptake and soil fertility in paddy-wheat rotation. Indian J. Agril. Res., 18: 7378.

Krishnamurthy, N., Abdul Khalak, Sujith, G. M., Basavaraj, H.K., Prasanna, K.P.R. and Shivaraj, B. 2002. Integrated nutrient supply and management (INSM) for potato production in alfisols. Potato, global research \& development, Proceedings of the Global Conference on Potato, New Delhi, India, 6-11.

Manjappa, K. 1999. Sustainable production of planted and ratoon crop of hybrid rice under lowlands in hill zone of Karnataka. Ph D. Thesis, University of Agricultural Sciences, Dharwad.

Mathur, G.M. 1997. Effect of long-term application of fertilizer and manures on soil properties and yield under cotton wheat rotation in North-WestRajasthan. J. Indian Soc. Soil Sci., 45: 288-292.

Mondal, S.S., Debabrata Acharya, Arup 
Ghosh. and Bug, A. 2005. Integrated nutrient management on the growth, productivity and quality of potato in Indo-Gangetic plains of West Bengal. Potato J., 32(1/2): 75- 78.

Ojha, R.K., Mandal, B.K., Pareta, D.K. and Thomas, T. 2009. Effect of combined application of inorganic, FYM and Azotobacter on chemical properties and N, P, K availability after potato harvest. Environ. Ecol., 27(4B): 1899-1902.

Olsen, S.R., Cole, C.V., Watanabe, F.S. and Dean, L.A. 1954. Estimation of available phosphorus in soils by extraction with sodium bicarbonate. U.S.D.A., Circular, 10: 939.

Pandey, P.K., Singh, S.K., Singh, S.V., Rawal, B.P. and Kumar, D. 2008. Evaluation of nutrient management options for potato processing cultivars. Potato J., 35(1/2): 46-52.

Raghav, M. and Shashi, Kamal. 2009. Effect of organic sources of nutrients on potato production in Tarai region of Uttarakhand, Pantnagar, J. Res., 7(1): 69-72.
Selvamani, P., Manivannam, K. and Mohan, J. 2011. Impact of organic manures, inorganic fertilizers and biofertilizers on the nutrient concentration in soil at different growth stages of banana cv. Pooran Mysore. Plant Archives, 11: 1165-1168.

Singh, F., Kumar, R., Pal, S. and Kumar, P. 2006. Sustainable production of scented rice (Oryza sativa) with manures and biofertilizers. Ann. Agric. Res. New Series, 27(4): 412- 413.

Singh, N.K., Kumar, Ashok. and Yadav, V.K. 2008. Integrated effect of organic and inorganic fertilizers on yield and quality of potato (Solanum tuberosum L.). Res. Crops, 9(2): 338-341.

Snedecor, G.W. and Cochran, W.G. 1967. Statistical method $6^{\text {th }}$ Ed. Oxford and IBH Publishing Corp, Calcutta.

Subbiah, B.V. and Asija, C.L. 1956. A rapid procedure for the determination of available nitrogen in soils. Curr. Sci., 25: 259-260.

Walkely, A. and Black, A.I. 1934. Analysis of organic carbon. Soil. Sci., 63-251.

\section{How to cite this article:}

Pradip Kumar, Alok Kumar, Neeraj Kumar, Atik Ahamad and Verma, M.K. 2017. Effect of integrated nutrient management on productivity and nutrients availability of potato. Int.J.Curr.Microbiol.App.Sci. 6(3): 1429-1436. doi: https://doi.org/10.20546/ijcmas.2017.603.162 